\title{
Continuous Information Support of the Curriculum Life Cycle within the Digital University
}

\author{
Galina V. Verkhova \\ Department of automation of communication enterprises \\ The Bonch-Bruevich Saint-Petersburg State University of \\ Telecommunications (SPbSUT) \\ St. Petersburg, Russia \\ galina500@inbox.ru
}

\author{
Sergei V. Akimov \\ Department of automation of communication enterprises \\ The Bonch-Bruevich Saint-Petersburg State University \\ of Telecommunications (SPbSUT) \\ St. Petersburg, Russia \\ akimov-sv@yandex.ru
}

\begin{abstract}
The paper presents the concept of continuous information support of the life cycle of the curriculums within the digital University. This concept assumes complex automation of development and adjustment of working curricula, training programs, funds of estimated means, electronic educational resources, planning and distribution of educational loading, and support of educational process staff. The paper shows that introduction of continuous information support of the life cycle of curriculums will ensure the transition of the process of targeted training of highly qualified personnel to a qualitatively new level, will increase the degree of individualization of the educational process, will minimize routine work on the preparation of supporting documentation, create conditions for replication of the best educational practices.
\end{abstract}

Keywords-digital university; information support of the curriculums life cycle; complex automation of university management; complex model of electronic educational resource; qualimetric model of educational resources; adaptive educational resources; qualimetric model of the student; indicators of achievement of competences set; e-learning; automation of management of individual trajectories of training

\section{INTRODUCTION}

In modern conditions, the training of highly qualified specialists is impossible without the introduction of the latest educational and information technologies. Modern realities require a radical revision of the existing system of management of higher education and the organization of the educational process. It is necessary to abandon outdated forms of document management, including the requirement to submit reports of student papers in paper form. In addition, there is a need for a radical reduction in the routine work of teachers to fill out multiple reports, often reduced to presenting the same information in different forms. As a result, one of the basic principles of modern information technology is violated"Don't repeat yourself, DRY" ("do not repeat yourself") [1]. In addition to wasting time, violation of the DRY pattern leads to errors, leading to inconsistency of documents (antipattern "False tile") [2].

The solution of the problems inherent in modern education (not only higher education) is possible within the framework of the introduction of the concept of "Digital University", which provides for a comprehensive Informatization of all processes of higher education within a single educational cyber environment. It should be noted that the digitalization of the educational process is not an end itself. Modern technologies should be subordinated to the main goal facing higher education, namely, formation of a creative personality of a specialist capable of self-development, self-education, and innovation [3]. Only such specialists can be classified as highly qualified personnel.

\section{DIGITAL UNIVERSITY, INFORMATION SOCIETY AND INDUSTRY 4.0}

The digital University should be based on a single cyber environment, created on the basis of three basic principles: 1) Agency, 2) information self-service and 3) managed information openness [4]. On the basis of these principles can also be created and a single cyber information society [5], formed in the merger of ciberred individual organizations. The academic cyber environment is which an Association of all educational environments, a part of a single cyber environment of the information society. Within the framework of the educational cyber environment of the digital University, continuous comprehensive information support of the life cycle of the main educational programs is carried out.

Given the trend of deep integration of computing resources into physical entities of any kind, cyber environments are often referred to as cyberphysical systems or cyberphysical environments. However, the term cyber environment does not contradict the possibility of integrating computing resources into physical entities, so these terms can be considered equivalent. In this article, we will use the term cyberphysical environment, if it is necessary to emphasize the phenomenon of "mixed" reality, assuming the above integration.

The concept of a digital University corresponds to the concept of" industry 4.0", which involves the mass introduction of cyber-physical systems into production [6-8]. Table 1 compares the basic concepts of "Industry 4.0" and "Digital University". 
COMPARATIVE ANALYSIS OF THE CONCEPTS "INDUSTRY 4.0" AND "DIGITAL UNIVERSITY"

\begin{tabular}{|c|c|}
\hline Industry 4.0 & Digital University \\
\hline $\begin{array}{l}\text { Cyberphysical system - } \\
\text { information technology system, } \\
\text { which implements a deep } \\
\text { integration of computing resources } \\
\text { into physical entities of any kind }\end{array}$ & $\begin{array}{l}\text { Cyberphysical educational } \\
\text { environment is an educational } \\
\text { environment that provides deep } \\
\text { integration of computing resources } \\
\text { into the educational process }\end{array}$ \\
\hline Deep customization of the product & Individual educational trajectory \\
\hline $\begin{array}{lll}\text { PLM }- & \text { product } & \text { lifecycle } \\
\text { management } & & \\
\end{array}$ & $\begin{array}{l}\text { Automated life cycle management } \\
\text { of curriculums }\end{array}$ \\
\hline $\begin{array}{l}\text { Smart Factory-seamless connection } \\
\text { of individual stages (operations) of } \\
\text { the production process, from the } \\
\text { stage of marketing research and } \\
\text { product design, to the organization } \\
\text { of production and process control, } \\
\text { to distribution, operation and } \\
\text { disposal }\end{array}$ & $\begin{array}{l}\text { Continuous information support of } \\
\text { the life cycle of the main } \\
\text { educational programs }\end{array}$ \\
\hline $\begin{array}{l}\text { Interoperability (functional } \\
\text { independence) - the ability of a } \\
\text { product or system whose interfaces } \\
\text { are fully open to interact and } \\
\text { function with other products or } \\
\text { systems without any restrictions on } \\
\text { access and implementation }\end{array}$ & $\begin{array}{l}\text { Interoperability of software and } \\
\text { algorithmic support and processes } \\
\text { of various digital universities, } \\
\text { colleges, schools and other } \\
\text { organizations, allowing to combine } \\
\text { the environment of individual } \\
\text { organizations into a single } \\
\text { academic cyber environment }\end{array}$ \\
\hline $\begin{array}{l}\text { IIoT is an industrial Internet of } \\
\text { things. Provides interaction of } \\
\text { physical production operations and } \\
\text { related processes }\end{array}$ & $\begin{array}{l}\text { AIoT is an academic Internet of } \\
\text { things. Provides interaction of the } \\
\text { objects which are a part of material } \\
\text { and technical support of } \\
\text { educational process }\end{array}$ \\
\hline
\end{tabular}

\section{AUTOMATED LIFE CYCLE MANAGEMENT OF CURRICULUMS}

Life cycle management of the main educational programs in the framework of the digital University involves a comprehensive end-to-end automation of the following processes (Fig. 1):

- development of working curriculum and working curricula of disciplines, practices and state final certification;

- student population management;

- personnel management of the educational process;

- management of material and technical support of the educational process;

- operational management and monitoring of the educational process.

Consistency of all processes and artifacts obtained at all stages of the life cycle of the main educational program requires a single model:

$$
C M=\langle P, S, R\rangle,
$$

where:

$C M$ - multidimensional model of the curriculum;

$P$ - the working curriculum and work programs, including the fund of assessment tools;
$S$ - stuff, material-technical and educational-methodical support of the curriculum;

$R$ - results of implementation of the curriculum.

The use of a single model (1) will provide the possibility of coordinated development of all artifacts of the basic educational program (working curriculum, work programs, evaluation Fund), as well as management of various types of support (personnel, logistics and training) and the process of implementation of the educational program (Fig. 2).

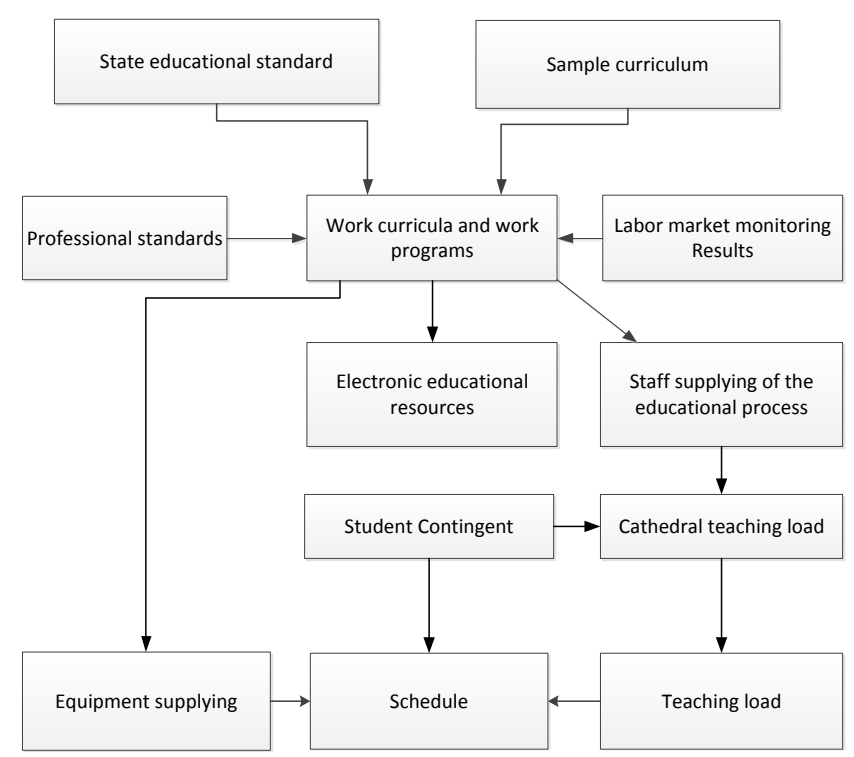

Fig. 1. General scheme of automation of curriculums life cycle management

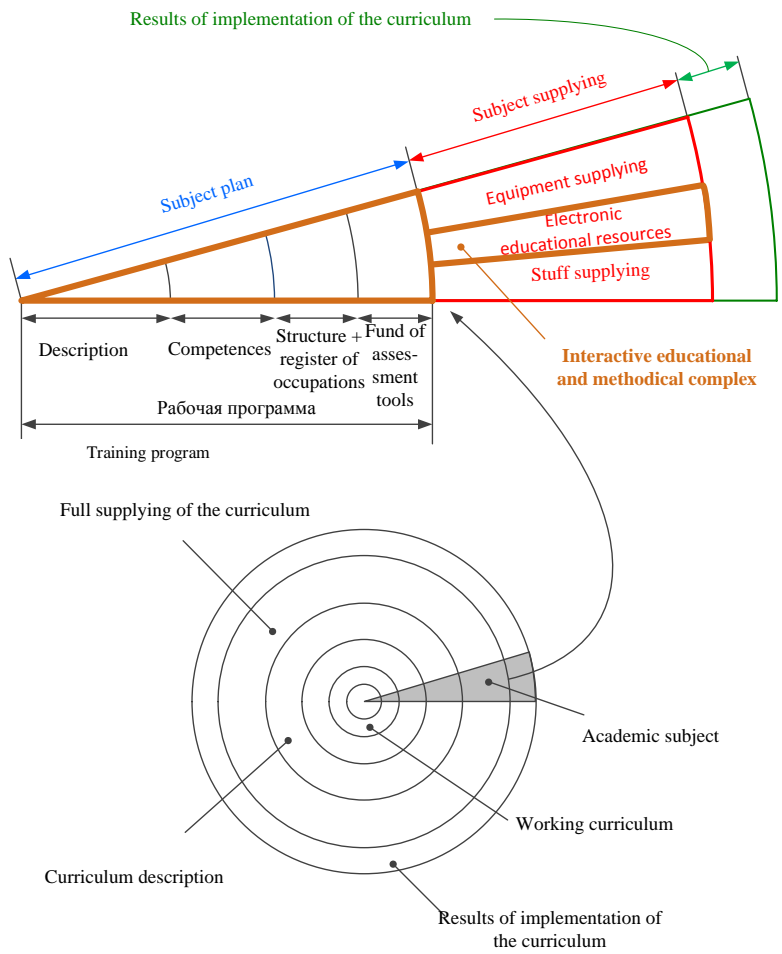

Fig. 2. Concentric model of the curriculum 
Briefly consider the process of developing and managing the implementation of the main educational program.

- The choice of the professional standards and employment of generalized functions, the definition of activities and professional competences.

- Planning for the cohort and study groups.

- Determination of the list of disciplines, their complexity, as well as other types of educational activities. Definition of connections between disciplines. Distribution of disciplines and other types of educational activities by semesters. The development of work programs and the Fund of assessment tools (within a single concentric model of discipline)

- Planning of personnel support of disciplines.

- Planning of material-technical and educationalmethodical support of disciplines. Formation of technical specifications for the creation (purchase) of the missing security elements.

- Calculation of Cathedral loads and load distribution between teachers of departments.

- Scheduling for the semester.

- Operational management of the implementation of the main educational program. Correction of artifacts obtained in the previous stages.

Within the framework of expression (1) the working curriculum, working curricula and the results of the current monitoring of the implementation of the main educational program (attendance, academic performance, etc.), some aspects of the $A_{I}$ multidimensional model can be considered:

$$
A_{i}=F_{i}(C M)
$$

Given that the model (1) contains all the necessary and upto-date information about all aspects of the main educational program (2), Most of the reports can be obtained only on the principle of "one button":

$$
\text { Report }_{i}=\text { ReportGenerator }_{i}\left(A_{i}, \text { Form }_{i}\right) \text {, }
$$

where:

$$
\begin{aligned}
& \text { Report }_{i} \text { - the report; } \\
& \text { Form }_{i} \text { - the report pattern; }
\end{aligned}
$$

ReportGenerator $_{i}$ - the report generator.

\section{CONCEPT OF ADAPTIVE EDUCATIONAL AND METHODICAL COMPLEXES}

Educational and methodological support of the main educational program implemented within the framework of the digital University must meet the following requirements:

- support for interactive forms of learning;
- $\quad$ support for all types and forms of classes (theoretical, practical, independent, individual, group, frontal);

- adaptation to the individual characteristics of students;

- ability to replicate the experience of leading teachers;

- modularity (the possibility of using the same modules in courses of different disciplines);

- support of concentric model of discipline course construction;

- availability of mechanisms for assessing the level of material assimilation [9-11] for current and intermediate certification.

Taking into account these requirements, the model of interactive educational and methodical complex can be presented in the following form (Fig. 3):

$$
E M C=\langle D, M, Q, R\rangle
$$

where:

$D$ - sections of interactive educational and methodical complex (theoretical part, exercises, etc.);

$M$ - module, which is the main component unit of interactive educational and methodical complex);

$Q$ - control and measuring materials;

$R-$ connections between separate elements of interactive educational and methodical complex.

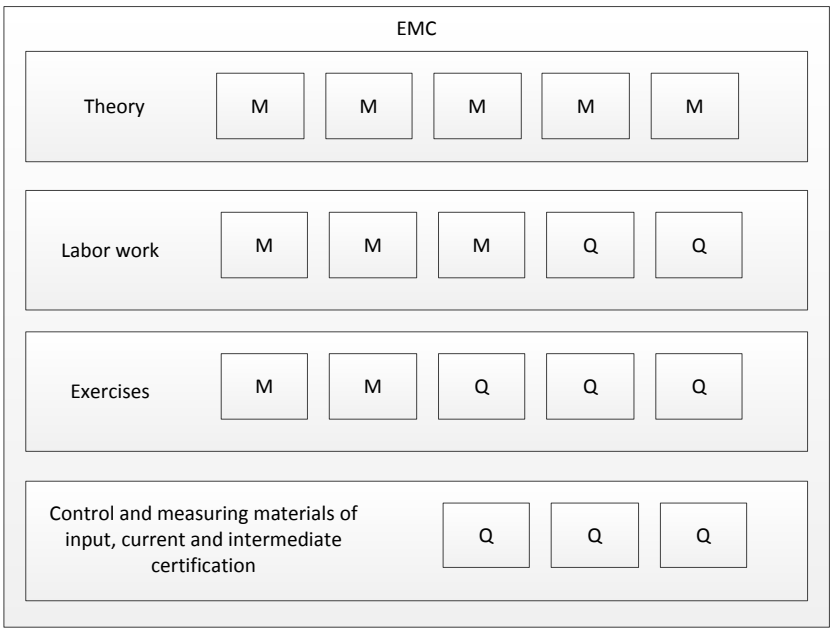

Fig. 3. Structure of interactive educational and methodical complex

A module can be represented by the following expression:

$$
M=\langle T, M M, Q, R>,
$$

where $Q$ are tasks for self-examination mastering of the passed material;

$M M$ - multimedia resource (image, video, audio);

$T-$ text block. 
The proposed model (4-5) provides the construction of interactive educational and methodical complexes from unified blocks. The same types of modules can be used in the creation of the theoretical part, laboratory and practical classes. Modules and test and measurement materials can be placed in the library and further used in the creation of other interactive teaching modules. According to the results of the entrance testing of knowledge, current and intermediate certification, a set of modules recommended for study by the student is automatically formed.

\section{CONCLUSION}

The concept of continuous information support of the life cycle of basic educational programs, presented in the article, is based on the use of multidimensional models that provide coordinated management of all processes, as well as a significant reduction in routine work. The proposed models are focused on the support of interactive forms of education taking into account the individual characteristics of students, as well as on the creation of a single library of electronic educational resources built on a modular principle.

\section{REFERENCES}

[1] Wilson G, Aruliah DA, Brown CT, Chue Hong NP, Davis M, Guy RT, et al. Best Practices for Scientific Computing. PLoS Biol 2014. No 12 (1). Pp. 1-7. [doi.org/10.1371/journal.pbio.1001745]

[2] Kim M., Bergman L., Lau T., Notkin D. Ethnographic Study of Copy and Paste Programming Practices in OOPL. Proceedings. 2004 International Symposium on Empirical Software Engineering, 2004 ISESE'04. Pp. 83-92. [doi:10.1109/ISESE.2004.1334896]

[3] Yurlovskaya I.A. Issledovanie teoretiko-metodicheskih interaktivnyh form vysshej shkoly. [The study of theoretical and methodological interactive forms of higher education] Mir nauki. [World of Science] 2014. № 1. P. 13. (In Russian)
[4] Verkhova G.V., Akimov S.V. The Role of the Unified Educational Cyber Environment in Improving the Quality of Training of Engineer Personnel. Proceedings of 2018 17th Russian Scientific and Practical Conference on Planning and Teaching Engineering Staff for the Industrial and Economic Complex of the Region, PTES 2018. Pp. 70-74. (SCOPUS, IEEE) [DOI: 10.1109/PTES.2018.8604190].

[5] Akimov S.V., Verhova G.V., Metkin N.P. Teoreticheskie osnovy CALS. [The theoretical foundations of CALS] SPb. SPbGUT Publ. [SPb. SPbSUT], 2018. 263 p. (In Russian)

[6] Kannengiesser U, Müller H. Multi-level, Viewpoint-Oriented Engineering of Cyber-Physical Production Systems: An Approach Based on Industry 4.0, System Architecture and Semantic Web Standards. 44th Euromicro Conference on Software Engineering and Advanced Applications (SEAA), 2018. Pp. 331-334. [DOI: 10.1109/SEAA.2018.00061].

[7] Cisneros-Cabrera S, Sampaio P, Mehandjiev N. A B2B Team Formation Microservice for Collaborative Manufacturing in Industry 4.0 // IEEE World Congress on Services (SERVICES). 2018. Pp. 37-38. [DOI: 10.1109/SERVICES.2018.00032]

[8] Chen G., Liu L., Qiang X., Liu Y. Industry 4.0 Development and Application of Intelligent Manufacturing // International Conference on Information System and Artificial Intelligence (ISAI), 2016. Pp. 407410. [DOI: 10.1109/ISAI.2016.0092].

[9] Grebenyuk T.B., Panyushkina M.A. Modelirovanie kvalimetricheskoj kompetentnosti na osnove koncepcii individual'nosti [Modeling of qualimetric competence based on the concept of individuality] Vestnik Baltijskogo federal'nogo universiteta im. I. Kanta. Ser.: Filologiva pedagogika, psihologiya. [Bulletin of the Baltic Federal University named after I. Kant. Ser .: Philology, pedagogy, psychology] 2016. № 2. Pp. 81-91. (In Russian)

[10] Vasil'eva N.O. Ocenka obrazovatel'nyh rezul'tatov studentov na osnove modeli kompetencij [Assessment of educational results of students on the basis of the competency model] Sovremennye problemy nauki $i$ obrazovaniya. [Modern problems of science and education] 2017. № 6. Pp. 177. (In Russian)

[11] Tkhagapsoyev K.G., Robert K.K., Martin M.Y. To Problems of Qualimetric Estimation of Quality in Education and Science. IEEE International Conference "Quality Management, Transport and Information Security, Information Technologies" (IT\&QM\&IS). 2018. Pp. 692-695 [DOI: 10.1109/ITMQIS.2017.8085918]. 